\title{
The Project Cost Risk Assessment Based On AHP
}

\author{
Huachao QIAN*, Qi WANG, Xiaowen LIU \\ The Student of Nanjing Forestry University, Nanjing, Jiangsu, China
}

\begin{abstract}
Influenced by a variety of factors, the cost is highly uncertain, and this means a great deal of risk exists in the cost estimating process. In fact there are relationships exist in these factors. This paper establish a indicator system for the cost risk evaluation on Jiao Balou based on extensive investigation and long-term practice. In addition, this paper find out the main factors affecting the project cost, and provides a theoretical basis for the formulation of reasonable cost by using AHP to calculation relative weight of each index. The evaluation system, evaluation method can be used for reference for similar project.
\end{abstract}

KEYWORDS: The Project Cost; AHP; Risk Assessment; Index System

\section{INTRODUCTION}

With the regulation and development of China's macroeconomic, the development of the construction is by leaps and bounds. There are some problems in its management although we have accumulated a lot of experience. Such as the construction market is not standardized, the lack of quality of the project and so on, but the most impertant issue is the higher project cost and risks. In recent years, many construction projects are overruns in varying degrees in the budget, final accounts and budget, resulting in many projects of investment out of control. The relationship between the various risk factors is complex, showing the link between the multilevel nature. With the implementation of the project, the risks faced by the cost of the project will change, which requires that we must do risk control project construction and management [3].

Currently, many scholars have done many associated researches on cost of risk.Wei Hong(2005) defined the cost of risk in project, then she determined the cost management objectives for each phase of the construction project by combining risk management level with the content of the project cost. Finally, she established a life cycle cost risk management system of a construction project. Liu Rubing (2009) proposed risk countermeasures for the establishment of risk management system. At the same time, Yang Tongwen (2013) and Sun Yiman (2014) analysised the response measures at the starting point of risk aversion. Risk has always been difficult to quantify, a large number of scholars have done many researches on risk and put forwand many measures, but more just from the narrative aspects. And Lu Lei (2009) used VaR theory, proposed extreme value distribution model based on a POT and got the corresponding VaR (Value at Risk) estimates by using GPD distribution. This paper analyzed the risks of the cost of the project and established risk system based on AHP. Trying to figure out the biggest risk factors of the cost and providing reference for similar projects.

\section{RISK EVALUATION INDEX SYSTEM OF PROJECT COST}

\subsection{Identify cost risk factors}

The main factors affecting the project cost includes funding, design and construction, which funds can be further divided into the amount of initial investment, bank lending rates, national policies, such as stability and reliability of post-funding. Design can be further divided into the design economy, the rationality of the material, safety margin and the maturity of design process. Construction can be further divided into the quantity machine price, consumption of fixed, temporary works facilities, transportation programs and fees, wind water and electricity consumption and unpredictable costs [1-2].

\subsection{Establish the index system of project cost risk}

From the present situation of the project cost, based 
on an analysis of relevant policies and theories of project cost to construct the target level, criteria level, index level and programs level. This indicator system includes three dimensions of financing, design, construction [4-5].

\section{PROJECT RISK ASSESSMENT METHODOLOGY}

\subsection{Project Cost Risk Assessment}

After establishing the project cost risk evaluation index system, we can combined with AHP to calculate the relative weight of each index, to calculate the overall weight of all index weight, to identify the main sources of risk affecting the project cost, in order to provide effective accordance for controling the project cost [4].

\subsubsection{Judgment matrix}

Judgment matrix scale, as shown in Table 1 below:

Table 1 Judgment matrix scale

\begin{tabular}{|l|l|}
\hline Scaling $\mathrm{a}_{\mathrm{ij}}$ & Definition \\
\hline 1 & $\mathrm{i}$ and $\mathrm{j}$ factors are equally important \\
\hline 3 & i factor is slightly more important than $\mathrm{j}$ factor \\
\hline 5 & i factors more important factor than $\mathrm{j}$ \\
\hline 7 & i factors very important factor than $\mathrm{j}$ \\
\hline 9 & i factors absolutely important factor than $\mathrm{j}$ \\
\hline $2,4,6,8$ & $\begin{array}{l}\text { intermediate state corresponding } \text { scale value } \\
\text { between these two }\end{array}$ \\
\hline Reciprocal & Compared $\mathrm{i}$ with $\mathrm{j}$, obtain the value: $\mathrm{a}_{\mathrm{ji}}=1 / \mathrm{a}_{\mathrm{ij}}$ \\
\hline
\end{tabular}

Organizing the project cost experts, scholars, designers and construction people into expert team for the index system. Then using expert investigation or brainstorming to compare element with each other. For the rule layer, establishing judgment matrix A as follows:

$$
A=\left[\begin{array}{lll}
1 & 2 & 0.20 \\
0.50 & 1 & 0.17 \\
5 & 6 & 1
\end{array}\right]
$$

Then we can obtain each judgment matrix of the criterion level following the same reason: $\mathrm{B}_{1}, \mathrm{~B}_{2}, \mathrm{~B}_{3}$.

\subsubsection{Calculating feature vectors of the Judgment matrix}

We can obtain relative weights by calculating and normalizing the eigenvectors of the Judgment matrix. Feature vectors can be obtained by calculating the characteristic roots, taking root, least squares methods. In this paper, after a comprehensive comparison, we finally adopt the square root method, which is calculated as Equation1:

$$
w_{i}=\left(\prod_{j-1}^{n} a_{i j}\right)^{\frac{1}{n}} / \sum_{k=1}^{n}\left(\prod_{j-1}^{n} a_{k j}\right)^{\frac{1}{n}}
$$

Taking calculating the eigenvectors of judgment matrixA as example: $\mathrm{W}_{\mathrm{A} 1}=0.172, \quad \mathrm{~W}_{\mathrm{A} 2}=0.102$, $\mathrm{W}_{\mathrm{A} 3}=0.726$. We can get the relative weight vector. We can also obtain the relative weights of the index level as $\mathrm{W}_{\mathrm{B} 1}, \mathrm{~W}_{\mathrm{B} 2}, \mathrm{~W}_{\mathrm{B} 3}$. Final weight calculation results and the overall ordering in Table 2.

\begin{tabular}{|c|c|c|c|c|c|}
\hline Target layer & Criterion level A & Index layer B & Relative weights & Overall weight & Sequence \\
\hline \multirow{14}{*}{$\begin{array}{l}\text { Project Risk } \\
\text { Evaluation }\end{array}$} & \multirow{4}{*}{ Fund $(0.172)$} & amount of initial investment & 0.233 & 0.040 & 9 \\
\hline & & bank lending rates & 0.138 & 0.024 & 10 \\
\hline & & national policies & 0.084 & 0.014 & 12 \\
\hline & & reliability of post-funding & 0.545 & 0.094 & 5 \\
\hline & \multirow{4}{*}{ Design (0.102) } & design economy & 0.545 & 0.056 & 8 \\
\hline & & the rationality of the material & 0.138 & 0.014 & 13 \\
\hline & & safety margin & 0.233 & 0.024 & 11 \\
\hline & & the maturity of design process & 0.084 & 0.009 & 14 \\
\hline & \multirow{6}{*}{ Construction(0.726) } & quantity machine price & 0.321 & 0.233 & 1 \\
\hline & & consumption of fixed & 0.138 & 0.100 & 4 \\
\hline & & temporary works facilities & 0.182 & 0.132 & 2 \\
\hline & & transportation programs and fees & 0.083 & 0.060 & 7 \\
\hline & & wind water and electricity consumption & 0.106 & 0.077 & 6 \\
\hline & & unpredictable costs & 0.170 & 0.123 & 3 \\
\hline
\end{tabular}

Table 2 Cost Risk Index weighting 


\subsubsection{Consistency check}

Firstly, calculating the compatibility index C.I. $=\left(\lambda_{\max }-n\right) /(n-1), \lambda_{\max }$ is the largest eigenvalue. Then follow $\mathrm{CR}=\mathrm{CI} / \mathrm{RI}$ consistency ratio is calculated, which is the average random consistency index RI, and its value as shown in Table 3

Table 3 Average consistency index R.I.

\begin{tabular}{|c|c|c|c|c|c|c|}
\hline Matrix order & 1 & 2 & 3 & 4 & 5 & 6 \\
\hline R.I. & 0 & 0 & 0.58 & 0.90 & 1.12 & 1.24 \\
\hline
\end{tabular}

We can consider establishing judgment matrix has a good consistency When $\mathrm{CR}<0.10$. After testing, all the judgment matrixes have a good consistency.

\section{CONCLUSION}

According to Table 2, we can see the impact of the project cost in descending top eight are: Quantity machine price, temporary works facilities, unpredictable costs, consumption norms, the latter funds reliability, wind and hydropower consumption, transportation programs, incidentals and design economy, and construction paly a major impact among them. We should develop cost control measures and make it effective implementation. Only do like this can we lower the cost and maximize economic of the projects.

\section{REFERENCES}

[1] Liu Rui, Zhang Yuqing, Zhao Zhenyu, a construction project schedule delays influencing factors, building the economy.

[2] Qijun Chen, from the Project Risk Analysis and Management, China Building Industry Press.

[3] Bamberg G, Spremann K (1981) Implications of constant risk aversion. Z Oper Res 25:205-224

[4] Pfingsten A (1989) Incentives to forecast honestly. In: Bamberg G, Spremann K (eds) Agency theory, information, and incentives. 2nd edn. Springer, Berlin Heidelberg New York, pp 117-133

[5] Damodar N. Gujarrti. Essentials of Econometries (3rd Edition). Beijing: China Machine Press, 2006 